\title{
Hoe kinderen reageren op reclame in online sociale netwerken: reclamewijsheid en de invloed van leeftijdsgenoten
}

\begin{abstract}
Deze studie ${ }^{\mathrm{I}}$ onderzoekt of kinderen (9-12 jaar) het doel van reclame in online sociale netwerken (Habbo) begrijpen en in welke mate zij gevoelig zijn voor de mening van leeftijdsgenoten met betrekking tot merknamen die in deze netwerken ingebed worden. Daarnaast wordt onderzocht hoe deze variabelen hun verlangen naar de geadverteerde merken in online sociale netwerken beïnvloeden.
\end{abstract}

\section{Inleiding}

Overal ter wereld besteden kinderen steeds meer tijd aan online sociale netwerken (Gutnick, Robb, Takeuchi \& Kotler, 20Iо; Ofcom, 20II). Online sociale netwerken zijn virtuele speeltuinen waar kinderen nieuwe en bestaande vrienden ontmoeten en met elkaar chatten en gamen. De meest populaire online sociale netwerken, zoals Neopets, Club Penguin en Habbo, trekken miljoenen jonge bezoekers per maand (Fielder, Gardner, Nairn \& Pitt, 2007; Beals \& Bers, 2009). Deze online sociale netwerken zijn niet alleen populair bij kinderen, maar ook bij adverteerders. Ze bieden een unieke omgeving voor adverteerders om met deze jonge doelgroep in contact te komen. Er is echter zeer weinig bekend over hoe kinderen reclame in online sociale netwerken ervaren en hoe zij hierop reageren (Van Reijmersdal, Jansz, Peters \& Van Noort, 20I0). Deze studie heeft als doel om dit steeds populairder wordende fenomeen verder te belichten. Inzicht verkrijgen in de reacties van

\footnotetext{
Noortje Slot (MSc) is communicatieadviseur bij Hollands Kroon. Contactgegevens: De Verwachting I, I76I VM Anna Paulowna. E-mail: noortjeslot@hollandskroon.nl, tel: o6-I2899555.

Esther Rozendaal (PhD) is universitair docent Persuasieve Communicatie aan de Radboud Universiteit Nijmegen. Contactgegevens: Behavioural Science Institute, Radboud Universiteit Nijmegen, Postbus 9104, 6500 HE Nijmegen. E-mail: e.rozendaal@maw.ru.nl, tel: 024-3612763.

Eva A. van Reijmersdal (PhD) is universitair docent Persuasieve Communicatie aan de Universiteit van Amsterdam. Contactgegevens: Amsterdam School of Communication Research ASCoR, Universiteit van Amsterdam, Kloveniersburgwal 48, IоI2 CX Amsterdam. E-mail: e.a.vanreijmersdal @uva.nl, tel: 020-5253986, fax: 020-525368I.

Moniek Buijzen (PhD) is professor Communicatie aan de Radboud Universiteit Nijmegen. Contactgegevens: Behavioural Science Institute, Radboud Universiteit Nijmegen, Postbus 9104, $6500 \mathrm{HE}$ Nijmegen. E-mail: m.buijzen@maw.ru.nl, tel: 024-3612763.
} 
kinderen op reclame in online sociale netwerken is niet alleen van theoretisch belang, maar kan ook bijdragen aan de ontwikkeling van een passend reclamebeleid.

In deze studie richten we ons op twee kenmerkende eigenschappen van reclame in online sociale netwerken. De eerste eigenschap is het hoge integratieniveau tussen reclame en entertainment. Reclameboodschappen in online sociale netwerken zijn volledig geïntegreerd in de entertainende content van de virtuele omgeving. Zo verschijnen merknamen niet alleen op reclamebanners, maar ook op virtuele producten of hebben zij zelfs een eigen virtuele 'merkomgeving'. Daarnaast kunnen adverteerders virtuele speurtochten, quizzen, events en competities organiseren waarmee kinderen prijzen kunnen winnen, volledig in de stijl van een product of merk (Habbo, 20I2; Van Reijmersdal et al., 20I0). Er wordt over het algemeen verondersteld dat kinderen moeite hebben de commerciële aard van dit soort geïntegreerde reclameboodschappen te herkennen en begrijpen. Dit zou kunnen resulteren in een sterkere beïnvloeding (Livingstone, 2009; Mallinckrodt \& Mizerski, 2007; Nairn \& Fine, 2008; Owen, Lewis, Auty \& Buijzen, 2009; Van Reijmersdal, Rozendaal \& Buijzen, 20II). Om die reden richten we ons specifiek op de kennis van kinderen over de geïntegreerde reclame in online sociale netwerken (ook wel reclamewijsheid genoemd) en hoe die kennis gerelateerd is aan hun beïnvloedbaarheid door reclame.

De tweede kenmerkende eigenschap van reclame in online sociale netwerken is haar sociale aard. In online sociale netwerken is de reclameboodschap geplaatst in een context waarbij de interactie tussen leeftijdsgenoten, de zogenoemde 'peers', een belangrijke rol speelt. Kinderen praten regelmatig met hun leeftijdsgenoten over merken (o.a. Mangleburg, Doney \& Bristol, 2004; Meyer \& Anderson, 2000; Nelson \& McLeod, 2005). Op die manier leren zij elkaars merkvoorkeuren kennen en houden ze daar rekening mee als ze zelf een merk beoordelen. Bij een vriendengroep horen is erg belangrijk voor kinderen en de bereidheid zich aan te passen aan de groep is erg groot (Boush, 200I; John, I999). Het is dan ook waarschijnlijk dat de invloed van leeftijdsgenoten zich ook voordoet in de context van online sociale netwerken. Dit kan ertoe leiden dat kinderen gevoeliger zijn voor beïnvloeding door reclame die zij tegenkomen in dit soort netwerken.

Samenvattend onderzoeken we in deze studie hoe twee kenmerkende eigenschappen van reclame in online sociale netwerken (de integratie en de sociale aard) de reactie van kinderen beïnvloedt. We richten ons op deze twee kenmerken van reclame in online sociale netwerken, omdat we verwachten dat de wisselwerking tussen deze eigenschappen en de ontwikkelingseigenschappen van kinderen (hun beperkt niveau van reclamewijsheid en hun hoge gevoeligheid voor de invloed peers) kan resulteren in een sterkere mate van gevoeligheid voor deze vorm van reclame. Onze studie heeft als eerste doel te onderzoeken in welke mate kinderen het doel 
van reclame in online sociale netwerken begrijpen. Het tweede doel is om te onderzoeken in welke mate kinderen gevoelig zijn voor de mening van leeftijdsgenoten over merknamen die in deze netwerken ingebed zijn. Het derde doel van onze studie is om te testen of reclamewijsheid en gevoeligheid voor de invloed van leeftijdsgenoten, kinderen beïnvloedt in hun verlangen naar de geadverteerde merken in online sociale netwerken.

In onze studie richten we ons op kinderen van 9 tot 12 jaar omdat de kinderen binnen deze leeftijdsgroep het meest geïnteresseerd zijn in online sociale netwerken (Fielder et al., 2007) en hun bereidheid zich aan de groep aan te passen zich op een hoogtepunt bevindt (John, I999; Valkenburg, 2004). Daarnaast wordt aangenomen dat de belangrijkste veranderingen in de ontwikkeling van reclamewijsheid plaatsvinden in deze leeftijdsgroep (John, I999). Er wordt zelfs gedacht dat de reclamewijsheid van kinderen ergens tussen 9 en I2 jaar een volwassen niveau bereikt (zie Gunter \& Furnham, I998; Valkenburg \& Cantor, 200I). Daarnaast wijzen informatieverwerkingstheorieën erop dat kinderen in deze leeftijdsgroep wel reclamewijs kunnen zijn, maar dat zij door gebrek aan cognitieve capaciteiten moeite kunnen hebben om die wijsheid te activeren en toe te passen wanneer ze geconfronteerd worden met reclame (Moses \& Baldwin, 2005; Roedder, I98I). Dit kan belangrijke consequenties hebben voor de relatie tussen reclamewijsheid en de gevoeligheid van 9 - tot I2-jarige kinderen voor reclame in online sociale netwerken.

\section{Reclamewijsheid}

Met reclamewijsheid wordt het begrip van de consument van de motieven, strategieën en tactieken van reclame bedoeld (Livingstone \& Helsper, 2006; Young I990). Verschillende theoretische modellen bieden inzicht in de specifieke onderdelen van reclamewijsheid (voor een overzicht zie Wright, Friestad \& Boush, 2005; Rozendaal, Lapierre, Van Reijmersdal \& Buijzen, 20II). In dit onderzoek richten we ons op vier belangrijke onderdelen van reclamewijsheid, namelijk (I) reclameherkenning, (2) begrip van de commerciële bron van reclame, (3) begrip van de persuasieve intentie van reclame en (4) een kritische houding tegenover reclame.

Uit verschillende empirische studies over reclamewijsheid van kinderen met betrekking tot televisiereclame is gebleken dat kinderen tot 5 jaar moeite hebben met het maken van onderscheid tussen reclame en televisieprogramma's. Daarnaast zien kinderen van deze leeftijd reclame vooral als entertainment. Vanaf 5 jaar beginnen kinderen wel onderscheid te maken tussen reclame en televisieprogramma's, voornamelijk gebaseerd op verschillen in perceptuele kenmerken, zoals duur, tempo en geluidsniveau (bijv. Butter, Popovich, Stackhouse \& Garner, I98I; Levin, Petros \& Petrella, I982; Stephens \& Stutts, I982). Als kinderen ongeveer 8 jaar zijn beginnen zij de bedoeling van reclame te begrijpen, maar een diepgaand inzicht in de persuasieve intentie van reclame is pas volledig ontwikkeld bij een kind van I2 jaar (Rozendaal, Buijzen \& Valkenburg, 2008). Tegelijk met de ontwikkeling van dit concep- 
tuele begrip van reclame, ontwikkelen kinderen ook een kritische houding ten opzichte van reclame (voor een overzicht zie John, I999; Kunkel et al., 2004).

De kritiek die in het publieke debat ten aanzien van geïntegreerde reclame, zoals reclame in online sociale netwerken, geuit wordt, richt zich voornamelijk op het idee dat kinderen moeite hebben met het begrijpen van dit soort reclame. Vergeleken met traditionele televisiereclame wordt aangenomen dat kinderen meer moeite hebben met het herkennen en begrijpen van geïntegreerde vormen van reclame, omdat deze reclame is ingebed en verborgen in entertainment. Hierdoor zouden kinderen een minder kritische houding tegenover dit soort reclame aannemen (Livingstone, 2009; Nairn \& Fine, 2008). Een aantal studies heeft inderdaad uitgewezen dat herkenning en begrip van ingebedde vormen van reclame (zoals het adverteren van merknamen in films, reclame in games en advergames) zich bij kinderen aanzienlijk later ontwikkelt dan de herkenning en het begrip van televisiereclame (Auty \& Lewis, 2004; Mallinckrodt \& Mizerski, 2007; Owen et al., 2009; Van Reijmersdal et al., 2OII). Zo ontdekte Van Reijmersdal en collega's (2OII) dat bijna de helft van de kinderen zich er niet van bewust was dat advergames gecreëerd waren door de geadverteerde merken en dat het spel hen probeerde te beïnvloeden. Het onderzoek liet ook zien dat kinderen de advergames erg leuk vonden. Dit suggereert dat zij niet kritisch tegenover de reclame stonden.

Tot op heden is er weinig bekend over de reclamewijsheid van kinderen met betrekking tot reclame in online sociale netwerken. Ons eerste onderzoeksdoel richt zich op het verkennen van de mate waarin kinderen reclamewijs zijn. Dit leidt tot de volgende onderzoeksvraag:

OVI: In welke mate (a) herkennen kinderen reclame in een online sociaal netwerk, (b) begrijpen zij de commerciële bron van de reclame, (c) begrijpen zij de persuasieve intentie van reclame en (d) hebben zij een kritische houding tegenover reclame?

Er wordt verondersteld dat een beperkt niveau van reclamewijsheid tot sterkere beïnvloeding leidt (zie Kunkel et al., 2004; Livingstone \& Helsper 2006). Van oudsher gaan de meeste theorieën over kinderen en reclame ervan uit dat reclamewijsheid functioneert als een soort afweermechanisme bij het verwerken van reclameboodschappen. In dit licht zullen kinderen die weinig of niet reclamewijs zijn minder goed in staat zijn reclame kritisch te verwerken. Dat maakt hen gevoeliger voor de werking van reclame waardoor zij eerder naar het geadverteerde product zullen verlangen (bijv. Brucks, Armstrong \& Goldberg, I988; Friestad \& Wright, I994).

In het hedendaags wetenschappelijk debat wordt aan deze traditionele aanname steeds meer getwijfeld. Empirisch bewijsmateriaal is schaars en niet overtuigend 
genoeg. Daarnaast hebben recente theoretische inzichten op het gebied van ontwikkelingspsychologie en reclameverwerking belangrijke beperkingen aangetoond van de werking van reclamewijsheid als afweermechanisme tegen reclame-effecten (Rozendaal et al., 20II). De belangrijkste tekortkoming van de traditionele aanname is dat het verschil tussen het hebben van reclamekennis en het gebruiken van die kennis als een kritisch afweermechanisme over het hoofd wordt gezien. Zelfs als we aannemen dat kinderen over de nodige reclamekennis beschikken, is het niet vanzelfsprekend dat zij die kennis ook daadwerkelijk activeren en gebruiken om reclame kritisch te verwerken (Brucks et al., I988; John, I999; Moses \& Baldwin, 2005). De kans dat kinderen hun reclamekennis als een afweermechanisme gebruiken, hangt namelijk sterk af van hun motivatie en bekwaamheid om reclame op een hoog elaboratieniveau te verwerken (zie Buijzen, Van Reijmersdal \& Owen, 20ıо; Chaiken, Liberman \& Eagly, I989; Petty \& Cacioppo, I986).

Zo beargumenteren Buijzen en collega's (2010) in hun reclameverwerkingsmodel dat een hoog niveau van verwerking nodig is voor het activeren en toepassen van relevante reclamegerelateerde kennis. Dit impliceert dat de motivatie en bekwaamheid van de ontvanger om een reclameboodschap te verwerken vrij hoog moeten zijn om ervoor te zorgen dat reclamekennis gebruikt wordt als kritisch afweermechanisme. De affectieve aard van op kinderen gerichte reclame in combinatie met de onvolgroeide cognitieve vaardigheden van kinderen maken het echter erg moeilijk om reclame op een hoog elaboratieniveau te verwerken. Daardoor is het onwaarschijnlijk dat zij hun reclamewijsheid in zullen schakelen als afweermechanisme (zie Buijzen et al., 2010; Harris, Brownell \& Gargh, 2009; Livingstone \& Helsper, 2006). Dit geldt met name voor geïntegreerde vormen van reclame, zoals brand placement in online sociale netwerken. Als gevolg van de ingebedde, subtiele en verborgen aard van dit soort reclame, zullen kinderen minder snel gebruik maken van hun reclamewijsheid als afweermechanisme (Moore \& Rideout, 2007; Nairn \& Fine, 2008).

Voor zover bij ons bekend, hebben slechts twee studies reclamewijsheid van kinderen onderzocht in relatie tot geïntegreerde reclame (Mallinckrodt \& Mizerski, 2007; Van Reijmersdal et al., 20II). Beide studies richtten zich op advergames en vonden geen relatie tussen het begrip van kinderen van de persuasieve intentie en de commerciële bron van reclame en hun houding en voorkeur voor het geadverteerde merk. Met andere woorden, uit deze studies blijkt dat de verschillende onderdelen van reclamewijsheid (namelijk reclameherkenning, begrip van de commerciële bron van reclame, begrip van de persuasieve intentie van reclame) geen invloed hebben op de reactie van kinderen op advergames.

De mogelijkheid bestaat dat een kritische houding ten opzichte van reclame (d.w.z. de evaluatieve dimensie van reclamewijsheid, zie Rozendaal et al., 20II) de manier waarop kinderen op reclame reageren wel zou kunnen veranderen. Dat wil zeggen 
dat kinderen die een kritischere houding hebben ten opzichte van reclame in het algemeen negatiever reageren als zij worden blootgesteld aan een specifieke reclameboodschap, wat hen vervolgens minder gevoelig kan maken voor de effecten ervan (Lutz, I985; McKenzie \& Lutz, I989; Zuwerink \& Devine, I996). Dit is een relatief makkelijk proces voor kinderen. Omdat dit proces gebaseerd is op een laag niveau van verwerking, wordt er weinig aanspraak gedaan op de cognitieve capaciteiten van kinderen (Rozendaal et al., 20II). De empirische literatuur over de reactie van kinderen op televisiereclame laat inderdaad zien dat kinderen met een kritischere houding ten opzichte van reclame ook een minder positieve houding en minder verlangen hebben naar het geadverteerde product (Buijzen, 2007; Rossiter \& Robertson, I974; Rozendaal, Buijzen \& Valkenburg, 2012).

Het is echter niet zeker of de hiervoor genoemde resultaten ook gelden voor reclame in online sociale netwerken. Daarom zullen we voor ons derde onderzoeksdoel testen of reclamewijsheid invloed heeft op het verlangen van kinderen naar de geadverteerde merken in online sociale netwerken en hoe dit verschilt voor de verschillende componenten van reclamewijsheid. Gebaseerd op de traditionele kijk op de rol van reclamewijsheid formuleren we de volgende hypothesen:

Hia: Evaluatieve reclamewijsheid (d.w.z. kritische houding tegenover reclame) is negatief gerelateerd aan het verlangen van kinderen naar het in online sociale netwerken geadverteerde merk.

Hib: Conceptuele reclamewijsheid (d.w.z. reclameherkenning, begrip van de commerciële bron van reclame, begrip van de persuasieve intentie van reclame) is negatief gerelateerd aan het verlangen van kinderen naar het in online sociale netwerken geadverteerde merk.

\section{Gevoeligheid voor de invloed van leeftijdsgenoten}

Peers (d.w.z. vrienden of klasgenootjes) spelen een belangrijke socialiserende rol bij de vorming van merkattitude en -voorkeuren van jonge mensen (bijv. Moschis \& Churchill, 1978). Wanneer kinderen zich ontwikkelen tot tieners, wordt het horen bij een vriendengroep steeds belangrijker (Boush, 200I; John, I999; Meyer \& Anderson, 2000). Ze beginnen te geloven dat het bezit van bepaalde producten en merken bepalend is voor de kwaliteit van hun vriendschap. De bereidheid zich aan te passen aan een vriendengroep is daarom hoog (Banjerjee \& Dittmar, 2008). Op deze manier stelt de peer-groep een normatieve standaard waarbij bepaalde producten cool en populair zijn. Dit wordt ook wel de normatieve invloed van peers genoemd (Bearden, Netemeyer \& Teel, 1989). Onderzoek naar de gevoeligheid voor de invloed van peers laat zien dat peers een belangrijke bron van informatie zijn over bepaalde producten en merken. Onderzoek heeft aangetoond dat kinderen en tie- 
ners vaak met hun vrienden over merken en reclame praten, hetgeen hun merk- en reclamehouding en koopgedrag beïnvloedt (Mangleburg \& Bristol, ı998, Mangleburg, Doney \& Bristol, 2004).

Het is aannemelijk dat invloed van peers zich ook voordoet bij online sociale netwerken, omdat sociale interactie met peers daarbij een centraal element is. Kinderen die lid zijn van een online sociaal netwerk chatten voortdurend met elkaar over verschillende onderwerpen, onder andere over de geadverteerde merken en producten in deze netwerken (Smolders \& Zonjee, 2008). Het belang van deze interacties tussen peers blijkt uit het feit dat sommige sociale netwerkwebsites adverteerders de mogelijkheid bieden om online conversaties die over hun merken en/of producten gaan te volgen (Sulake 2009). Kinderen leren van de mening van peers en houden rekening met deze mening bij hun eigen beoordeling van merken. De invloed van peers kan zich dus voordoen bij merken in het algemeen, maar ook bij geadverteerde merken in online sociale netwerken. In de context van dit onderzoek zijn wij vooral geïnteresseerd in de invloed van peers met betrekking tot de geadverteerde merken in online sociale netwerken. Vanwege de mogelijk belangrijke rol van peers als het gaat om merken in het algemeen, houden we ook rekening met deze variabele.

Ons tweede onderzoeksdoel is het onderzoeken van de mate waarin kinderen gevoelig zijn voor de mening van peers over merken in online sociale netwerken. Om die reden stellen we de volgende onderzoeksvraag op:

OV2: In welke mate zijn kinderen gevoelig voor de mening van peers met betrekking tot merken in online sociale netwerken?

Ons derde onderzoeksdoel is om te testen of de gevoeligheid voor de mening van peers invloed heeft op het verlangen van kinderen naar de geadverteerde merken in online sociale netwerken. We onderzoeken daarom de volgende hypothese:

H2: De gevoeligheid voor de mening van peers is positief gerelateerd aan het verlangen van kinderen naar het in online sociale netwerken geadverteerde merk.

\section{Methode}

\section{Steekproef}

In totaal deden I55 kinderen van 9 tot I2 jaar mee aan het onderzoek. Voor de analyses werden 7 kinderen verwijderd vanwege ontbrekende data, wat resulteerde in een totale steekproef van I48 $\left(M_{\text {leeftijd }}=\right.$ IO.I2, $\left.S D=.99\right)$. De gegevens werden verzameld op twee basisscholen in Nederland. De steekproef bestond uit 85 jongens $(57 \%)$ en 63 meisjes $(43 \%)$. 


\section{Materiaal}

Deze studie richtte zich op Habbo, een van de grootste online sociale netwerken ter wereld voor kinderen en tieners. Het spel heeft meer dan 200 miljoen geregistreerde spelers in meer dan I50 landen. Habbo is een virtueel hotel waarin kinderen elkaar kunnen ontmoeten door middel van gepersonaliseerde avatars. In het hotel bevindt zich een grote verscheidenheid aan kamers. Er zijn openbare kamers gemaakt door Habbo waar alle spelers met elkaar kunnen chatten, zoals een bibliotheek, enkele restaurants, cafés en winkels. Spelers kunnen ook hun eigen hotelkamer inrichten met meubels en hun vrienden uitnodigen voor een feest. Daarnaast kunnen zij een huisdier adopteren om voor te zorgen. In Habbo bevinden zich ook verschillende minigames en komen er geregeld beroemdheden op bezoek. Habbo is gratis, maar om meer uit het spel te halen kunnen spelers ook Habbo-credits kopen, de officiële munteenheid van Habbo. Met deze credits kunnen zij virtuele artikelen kopen, zoals meubels om mooiere hotelkamers te maken of kaartjes voor een Habbo-evenement.

Voor onze studie is een videocompilatie gemaakt van Habbo. We hebben voor deze compilatie gebruik gemaakt van bestaande kamers en ruimtes in Habbo. De merken die kinderen te zien kregen, waren dus merken die kinderen ook echt tegen kunnen komen als zij zich door Habbo bewegen. De compilatie liet een avatar zien die door zes verschillende openbare ruimtes in Habbo liep. Vier van deze ruimtes bevatten een bepaalde vorm van reclame: (I) de ING-lounge, een kamer die exact op een echt kantoor van de ING Bank leek. Zo hing daar het ING-logo en was er een banner te zien waarop stond 'regel je eigen bankzaken met Bizznizz' (Bizznizz is een online tool voor jonge mensen om bankzaken te regelen ); (2) de MTV-kamer, een kamer die exact lijkt op een muziektheater inclusief verschillende merklogo's van MTV, (3) een ruimte voor de ingang van het $M T V$-theater met een logo van het computermerk DELL en (4) een snackbar met een banner van Website van het Jaar waarop stond: 'stem op Habbo'. De twee overige kamers, een park en een café, bevatten geen enkele vorm van reclame. De videocompilatie was 3.30 minuten lang en bevatte geen geluid omdat in Habbo ook geen geluid te horen is. We hebben ervoor gekozen de kinderen een videocompilatie te laten zien in plaats van hen zelf door Habbo te laten lopen om ervoor te zorgen dat alle kinderen dezelfde kamers en dezelfde advertenties zouden zien gedurende dezelfde tijd.

\section{Onderzoeksdesign}

Vanwege de exploratieve aard van het onderzoek is een descriptief-correlationeel design gebruikt. Blootstelling aan reclame in Habbo was gelijk voor alle kinderen. Reclamewijsheid en gevoeligheid voor de mening van peers werden gemeten als onafhankelijke variabelen en verlangen naar de geadverteerd merken als de afhankelijke variabele. 


\section{Procedure}

Voorafgaand aan het onderzoek is toestemming gevraagd aan de school en aan de ouders van de te onderzoeken leerlingen. Aan de kinderen is voorafgaand aan het onderzoek klassikaal uitgelegd dat het onderzoek over reclame op internet zou gaan en dat zij op elk moment mochten stoppen met het onderzoek. Een vrouwelijke onderzoeker bracht telkens twee kinderen naar de computerruimte van de school. $\mathrm{Na}$ een korte introductie bekeken de kinderen ieder afzonderlijk de Habbo-videocompilatie op een van de laptops van de onderzoekers. Na het kijken werd de kinderen gevraagd een online vragenlijst op de computer in te vullen.

In de vragenlijst werd gestart met algemene vragen zoals geslacht, leeftijd en groep. Daarna werd het verlangen van de kinderen naar de geadverteerde merken in Habbo gemeten, alsook hun conceptuele reclamewijsheid (d.w.z. reclameherkenning in Habbo, begrip van de commerciële bron van reclame en begrip van de persuasieve intentie van reclame) en hun evaluatieve reclamewijsheid (kritische houding ten opzichte van reclame in $\mathrm{Habbo}$ ). Als laatste werd de gevoeligheid voor de mening van peers in het algemeen en met betrekking tot de advertenties in Habbo gemeten. Nadat de kinderen klaar waren met het invullen van de vragenlijst werden ze teruggebracht naar hun klaslokaal en gevraagd niet met andere kinderen in hun klas over het onderzoek te praten totdat alle kinderen hadden deelgenomen. De leerkracht werd gevraagd hierop toezicht te houden. Het gehele onderzoek duurde ongeveer 30 minuten per kind.

\section{Variabelen}

Reclamewijsheid. Er werden vier aspecten van conceptuele reclamewijsheid gemeten: (I) reclameherkenning, (2) begrip van de commerciële bron van reclame, (3) begrip van de persuasieve intentie van reclame en (4) een kritische houding ten opzichte van reclame. Reclameherkenning werd gemeten door de kinderen schermafdrukken te tonen van de zes kamers in de Habbo-videocompilatie. Hierbij werd hen gevraagd om elk merk aan te wijzen dat zij zagen (zie Ali, Blades, Oats \& Blumberg, 2009). Er werd een schaal gevormd door het aantal correct geïdentificeerde merken bij elkaar op te tellen.

Voor de meting van het begrip van de kinderen van de commerciële bron en de persuasieve intentie van reclame hebben we een specifiek voorbeeld van een reclame in Habbo gebruikt om de vraag concreter te maken. Doordat kinderen jonger dan I2 jaar over beperkte informatieverwerkingscapaciteiten beschikken, hebben zij nog moeite met abstracte kennisvragen. Een voorbeeld kan hen helpen de vraag beter te begrijpen en de desbetreffende kennis te activeren (Martin, I997; Roedder, I98I). Het begrip van de commerciële bron van reclame werd gemeten door de kinderen een schermafdruk te tonen van de ING-lounge. De onderzoeker vertelde de kinderen eerst dat de kamer reclame bevatte en legde vervolgens uit dat zij dit konden herkennen aan de aanwezigheid van het IN- logo en een spandoek op de muren van de 
kamer. Vervolgens werd hen de vraag gesteld: 'Wie heeft deze reclame in Habbo gemaakt?’, waarna zij konden kiezen uit de volgende antwoorden: 'de makers van Habbo', 'de ING Bank', 'de onderzoekers', 'andere Habbo-spelers', 'de persoon die het Habbo filmpje heeft gemaakt' of 'ik weet het niet' (zie Van Reijmersdal, Rozendaal \& Buijzen, 20II). Het tweede antwoord werd gecodeerd met een I (juiste antwoord) en de overige antwoorden werden gecodeerd met een o (onjuiste antwoorden).

Het begrip van de persuasieve intentie van reclame is gemeten door de kinderen een schermafdruk te laten zien van de ING-lounge en hen hierover twee vragen te stellen, namelijk: 'Is deze reclame in Habbo bedoeld om ervoor te zorgen dat jij de ING Bank leuk gaat vinden?' en 'Is deze reclame in Habbo bedoeld om ervoor te zorgen dat jij een bankrekening bij de ING gaat openen?’. De antwoordmogelijkheden waren I (nee, zeker niet), 2 (nee, ik denk het niet), 3 (ja, ik denk het wel) en 4 (ja, zeker) (Rozendaal, Buijzen \& Valkenburg, 2008). Er is een schaal gevormd door het gemiddelde te nemen van de scores op de twee vragen $(r=.30, p<$. . o $)$.

Om de kritische houding tegenover reclame te meten werd de kinderen de volgende twee vragen gesteld: 'Denk jij dat reclame in Habbo je nuttige informatie biedt over producten?', en 'Vind je het leuk om reclame in Habbo te zien?' (gebaseerd op Van Reijmersdal, 20II). De antwoordmogelijkheden waren I (nee, zeker niet), 2 (nee, ik denk het niet), 3 (ja, ik denk het wel) en 4 (ja, zeker). Er is een schaal gevormd door de items eerst te hercoderen I (ja, zeker), 2 (ja, ik denk het wel), 3 (nee, ik denk het niet) en 4 (nee, zeker niet), zodat een hogere score een kritischere houding weergeeft, en vervolgens het gemiddelde te nemen van de scores op de twee vragen $(r=.28, p<$. OI $)$.

Gevoeligheid voor de mening van peers. De gevoeligheid voor de mening van peers over merken in het algemeen werd gemeten door de volgende twee vragen te stellen: 'Wil je alleen merken en producten hebben die je vrienden en klasgenootjes goedkeuren?' en 'Vind je het belangrijk dat je vrienden en klasgenootjes jouw merken en producten leuk vinden?'. De antwoordmogelijkheden waren I (nee, zeker niet), 2 (nee, ik denk het niet), 3 (ja, ik denk het wel) en 4 (ja, zeker). Er is een schaal gevormd door het gemiddelde te nemen van de scores op de twee vragen $(r=.32$, $p<.001)$.

De gevoeligheid voor de mening van peers met betrekking tot de geadverteerde merken in Habbo werd gemeten door de volgende vraag: 'Als je vrienden en klasgenootjes een merk willen hebben dat geadverteerd wordt in Habbo, wil jij dat dan ook?'. De antwoordmogelijkheden waren I (nee, zeker niet), 2 (nee, ik denk het niet), 3 (ja, ik denk het wel) en 4 (ja, zeker). 
TABEL 1. Het niveau van reclamewijsheid en de gevoeligheid voor de mening van peers

\begin{tabular}{|c|c|}
\hline Variabelen & $\begin{array}{l}\text { Kinderen } \\
(N=148)\end{array}$ \\
\hline Reclamewijsheid & $\%$ \\
\hline \multicolumn{2}{|l|}{ Reclameherkenning } \\
\hline Herkende 4 reclames & 57 \\
\hline Herkende 3 reclames & 37 \\
\hline Herkende 2 reclames & 5 \\
\hline Herkende I reclame & $\circ$ \\
\hline Herkende geen reclames & I \\
\hline \multicolumn{2}{|l|}{ Begrip van de commerciële bron } \\
\hline De makers van Habbo & 32 \\
\hline ING Bank (= correct begrip) & 43 \\
\hline De onderzoeker & I \\
\hline Andere Habbo-spelers & 3 \\
\hline Degene die de video die je net zag heeft gemaakt & 9 \\
\hline Ik weet het niet & $\mathrm{I} 2$ \\
\hline \multicolumn{2}{|l|}{ Begrip van de persuasieve intentie } \\
\hline Nee, zeker niet (= lage mate van begrip) & IO \\
\hline Nee, ik denk het niet & 27 \\
\hline Ja, ik denk het wel & 53 \\
\hline Ja, zeker (= hoge mate van begrip) & Io \\
\hline \multicolumn{2}{|l|}{ Houding ten opzichte van reclame } \\
\hline Ja, zeker (= weinig kritische houding) & 32 \\
\hline Ja, ik denk het wel & 38 \\
\hline Nee, ik denk het niet & 22 \\
\hline Nee, zeker niet (= zeer kritische houding) & 8 \\
\hline \multicolumn{2}{|l|}{ Gevoeligheid voor de mening van peers } \\
\hline \multicolumn{2}{|l|}{ Peerinvloed merken in het algemeen } \\
\hline Nee, zeker niet (= lage mate van peergevoeligheid) & 36 \\
\hline Nee, ik denk het niet & 49 \\
\hline Ja, ik denk het wel & I6 \\
\hline Ja, zeker (= hoge mate van peergevoeligheid) & I \\
\hline \multicolumn{2}{|l|}{ Peerinvloed merken in Habbo } \\
\hline Nee, zeker niet (= lage mate van peergevoeligheid) & 49 \\
\hline Nee, ik denk het niet & 30 \\
\hline Ja, ik denk het wel & I6 \\
\hline Ja, zeker (= hoge mate van peergevoeligheid) & 5 \\
\hline
\end{tabular}


Verlangen naar geadverteerde merken. Het verlangen naar de geadverteerde merken in Habbo werd gemeten door de kinderen twee vragen te stellen, namelijk: 'Wil je de merken die je in Habbo hebt gezien ook in het echt hebben?' en 'Ga je aan je ouders vragen om de merken die je in Habbo hebt gezien voor je te kopen?'. De antwoordmogelijkheden waren I (nee, zeker niet), 2 (nee, ik denk het niet), 3 (ja, ik denk het wel) en 4 (ja, zeker) (D’Alessio, Laghi \& Baiocco, 2009; Rozendaal, Buijzen \& Valkenburg, 2009). Er is een schaal gevormd door het gemiddelde te nemen van de scores op de twee vragen $(r=.48, p<$. .o I).

Achtergrondkenmerken. De kinderen werd gevraagd naar hun leeftijd, geslacht en hoe vaak zij Habbo bezoeken of, zoals kinderen zelf zeggen, Habbo spelen. De speelfrequentie van Habbo werd gemeten door de volgende vraag: 'Hoe vaak speel je Habbo?'. De antwoordmogelijkheden waren I (nooit), 2 (soms), 3 (vaak) en 4 (erg vaak).

\section{Resultaten}

\section{Niveau van reclamewijsheid bij kinderen en de mening van peers}

Ons eerste en tweede doel was het onderzoeken van de mate waarin kinderen reclamewijs zijn wanneer het gaat om reclame in online sociale netwerken (OVI) en de mate waarin ze gevoelig zijn voor de mening van peers met betrekking tot merken in online sociale netwerken (OV2). Om deze onderzoeksvragen te beantwoorden hebben we frequentieanalyses uitgevoerd met alle relevante variabelen. Percentages worden weergegeven in tabel I. De percentages van de samengestelde variabelen (begrip persuasieve intentie, houding ten opzichte van reclame, en peerinvloed merken $\mathrm{Habbo}$ ) zijn berekend door eerst de gemiddelde scores te berekenen (range = I-4) en deze scores vervolgens naar beneden af te ronden op ronde getallen (I,5 wordt I; 2,5 wordt 2; etc.) en te labelen met de bijbehorende antwoordcategorie (bijvoorbeeld I = 'nee, zeker niet').

Met betrekking tot het niveau van reclamewijsheid van de kinderen, bleek uit de analyses dat $57 \%$ van de kinderen alle vier de reclames in Habbo herkende. $37 \%$ herkende drie reclames en de overige $6 \%$ herkende twee reclames of minder. Daarnaast had $43 \%$ inzicht in de commerciële bron van reclame (d.w.z. ING Bank) en begreep $63 \%$ de persuasieve intentie van de reclame (het percentage van de kinderen dat zei 'Ja, dat denk ik wel' en 'Ja, zeker'.) Verder had 30\% van de kinderen een kritische houding tegenover reclame in Habbo (het percentage van kinderen dat zei 'nee, ik denk het niet' en 'nee, zeker niet'). Tot slot bleek slechts I7\% van de kinderen gevoelig te zijn voor de mening van peers over merken in het algemeen en zei $2 \mathrm{I} \%$ van de kinderen gevoelig te zijn voor de mening van peers met betrekking tot merken en producten in Habbo (percentage van de kinderen dat zei 'ja, ik denk het wel' en 'ja, zeker'). 
TABEL 2. Voorspelling van het verlangen naar geadverteerde merken in online sociale netwerken

\begin{tabular}{|c|c|c|c|}
\hline & \multicolumn{3}{|c|}{ Verlangen naar geadverteerde merken } \\
\hline & $\boldsymbol{\beta}$ & $S E$ & $r$ \\
\hline \multicolumn{4}{|l|}{ Controle variabelen } \\
\hline Leeftijd &.- .08 & $(.07)$ & -.15 \\
\hline Geslacht $(\mathrm{I}=$ meisjes $)$ & -.II & $(.13)$ & -.10 \\
\hline Speelfrequentie $\mathrm{Habbo}$ & .04 & $(. \circ 8)$ & .02 \\
\hline \multicolumn{4}{|l|}{ Reclamewijsheid } \\
\hline Reclameherkenning &.- .06 & $(.09)$ &.- .09 \\
\hline Begrip commerciële bron &.$- \mathrm{IO}$ & (.I2) & -.13 \\
\hline Begrip persuasieve intentie & .09 & $(.09)$ & $.20^{*}$ \\
\hline Kritische houding t.o.v. reclame & $-.34^{* \ldots * *}$ & $(. .8)$ & $-.46^{* * * * *}$ \\
\hline \multicolumn{4}{|l|}{ Gevoeligheid voor peerinvloed } \\
\hline Peerinvloed merken i.h. algemeen &.- .03 &. II & .08 \\
\hline Peerinvloed merken in Habbo & $37^{* \ldots * x}$ & $(. \circ 8)$ & $.50^{* \ldots *}$ \\
\hline$N$ & $\mathrm{I} 48$ & & \\
\hline Totaal $R^{2}$ (aangepast) & .36 & & \\
\hline
\end{tabular}

$\beta=$ genormaliseerde betaregressiecoëfficiënten; $S E=$ standaardfouten; $r=$ correlaties verlangen naar geadverteerde merk

$* p \leq .05 . * * p \leq .01 . * * * p \leq .001$.

\section{Effect van reclamewijsheid en mening van peers op het verlangen naar merken}

Ons derde onderzoeksdoel was om het effect van reclamewijsheid en gevoeligheid voor de mening van peers te testen op het verlangen van kinderen naar de in online sociale netwerken geadverteerde merken en producten (Hi en $\mathrm{H} 2$ ). Om deze hypotheses te toetsen is een regressieanalyse uitgevoerd met het verlangen naar het geadverteerde merk als afhankelijke variabele en reclamewijsheid (d.w.z. reclameherkenning, begrip van de commerciële bron van reclame, begrip van de persuasieve intentie van reclame, kritische houding) en gevoeligheid voor de mening van peers (d.w.z. gevoeligheid voor de mening van peers in het algemeen en met betrekking tot merken in $\mathrm{Habbo}$ ) als onafhankelijke variabelen. Leeftijd, geslacht en de speelfrequentie van Habbo werden als controle variabelen toegevoegd.

De resultaten van de regressieanalyse zijn weergegeven in tabel 2 . De tolerantiewaarden van de onafhankelijke variabelen variëren tussen de .72 en .99 en de VIFwaarden tussen de I.०o en I.38. Dit wijst erop dat er geen sprake is van multicollineariteit. Zoals in de tabel te zien is, bleek de regressieanalyse van het verlangen van kinderen naar merken en producten in online sociale netwerken als afhankelijke variabele significant te zijn, met een verklaarde variantie van $36 \%$. De grootste voorspeller voor het verlangen naar merken en producten bleek te zijn: een kritische 
houding tegenover reclame $(\beta=-.34, p<.00 \mathrm{I})$ en gevoeligheid voor de mening van peers met betrekking tot merken in Habbo $(\beta=.37, p<.00 \mathrm{I})$. Geen van de andere voorspellers bleek echter significant te zijn. Om die reden worden Hia en $\mathrm{H} 2$ bevestigd en Hib verworpen door de onderzochte gegevens.

\section{Discussie}

Het doel van deze studie was te onderzoeken hoe twee kenmerkende eigenschappen van reclame in online sociale netwerken (d.w.z. de integratie en de sociale aard) de reacties van kinderen op de ingebedde merken beïnvloeden. We onderzochten het niveau van reclamewijsheid en de gevoeligheid voor de mening van peers met betrekking tot merken en producten in online sociale netwerken. Daarnaast onderzochten we hoe reclamewijsheid en de gevoeligheid voor de mening van peers het verlangen naar de geadverteerde merken in online sociale netwerken van kinderen beïnvloeden.

\section{Het niveau van reclamewijsheid bij kinderen en de gevoeligheid voor mening van peers}

Met betrekking tot het eerste onderzoeksdoel laten de resultaten van ons onderzoek zien dat 9- tot I2-jarigen vrij goed in staat zijn om reclame in online sociale netwerken te herkennen. Bijna twee derde van de kinderen herkende alle vier de getoonde reclames in Habbo. Een derde van de kinderen herkende drie van de vier reclames. Daarnaast begreep $43 \%$ van de kinderen wie de commerciële bron van de reclame was en begreep $63 \%$ de persuasieve intentie. Deze percentages komen sterk overeen met de bevindingen van Van Reijmersdal et al. (20II) in een onderzoek naar advergames. In dit onderzoek toonde $40 \%$ van de kinderen een goed begrip van de bron en $57 \%$ van de persuasieve intentie. Toch zijn onze percentages beduidend lager vergeleken met reclamewijsheid van kinderen bij traditionele televisiereclame (Owen et al., 2009; Rozendaal et al., 2008). Alhoewel deze bevindingen de veronderstelling staven dat kinderen een minder goed inzicht hebben in niet-traditionele vormen van reclame in vergelijking met traditionele televisiereclame, is de herkenning en het begrip van reclame in online sociale netwerken bij kinderen toch relatief hoog. Opmerkelijk is dat de meerderheid van de kinderen in onze steekproef geen kritische houding heeft ten opzichte van reclame in online sociale netwerken.

Met betrekking tot ons tweede onderzoeksdoel kunnen we op basis van de resultaten stellen dat weinig kinderen (I7\%) gevoelig bleken voor de mening van peers met betrekking tot merken in het algemeen. Iets meer kinderen $(2 \mathrm{I} \%)$ gaven aan gevoelig te zijn voor de mening van peers met betrekking tot merken in Habbo. Deze relatief lage scores kunnen worden verklaard door het zogenoemde derdepersoonseffect (Davidson, I983). Met betrekking tot reclame hebben mensen de neiging om te zeggen dat zijzelf niet beïnvloed worden maar anderen wel. Dit fenomeen komt niet alleen voor bij volwassenen (Salwen \& Dupagne, 2003), maar ook bij kinderen 
(Henriksen \& Flora, I999). Daarnaast kunnen de lage scores ook verklaard worden door het halo-effect (Beckwith, Kassarjian \& Lehmann, I978). De merken die in de videocompilatie te zien waren, waren wellicht niet interessant voor kinderen. Als een merk kinderen niet of nauwelijks aanspreekt, bestaat de kans dat zij het ook niet interessant vinden om het merk met hun leeftijdsgenoten te bespreken of er hun groepsstatus mee te toetsen. De resultaten hadden anders kunnen zijn indien er meer doelgroepaansprekende merken gebruikt waren. De werkelijke gevoeligheid van kinderen voor de mening van peers met betrekking tot merken in het algemeen en merken in online sociale netwerken kan dus hoger zijn. Bovendien wordt het belang van peers in de gevoeligheid voor reclame in online sociale netwerken bevestigd door onze regressieanalyse, die aantoont dat de gevoeligheid voor de mening van peers een zeer significante voorspeller is van de houding van kinderen ten opzichte van geadverteerde merken binnen het spel.

\section{Het effect van reclamewijsheid en mening van peers op merkverlangen}

Met betrekking tot ons derde onderzoeksdoel laten de bevindingen van het onderzoek zien dat de evaluatieve component van reclamewijsheid (d.w.z. een kritische houding ten opzichte van reclame) en de gevoeligheid voor de mening van peers de belangrijkste voorspellers zijn voor het verlangen van kinderen naar de geadverteerde merken in online sociale netwerken. De conceptuele component van reclamewijsheid (d.w.z. reclameherkenning, begrip van de commerciële bron van reclame en begrip van de persuasieve intentie van reclame) spelen geen rol.

Onze meting voor begrip van de commerciële bron van reclame bevatte verschillende antwoord categorieën, namelijk 'de makers van Habbo', 'de ING Bank', 'de onderzoekers', 'andere Habbo-spelers', 'de persoon die het Habbo-filmpje heeft gemaakt' of 'ik weet het niet'. Hierbij werd 'de ING Bank' als het correcte antwoord gezien. Men zou echter kunnen beargumenteren dat het antwoord 'de makers van Habbo' ook een correct antwoord is, omdat de makers van Habbo een financieel belang hebben bij de advertenties. Om te onderzoeken of het goed rekenen van dit antwoord tot andere resultaten zou leiden, hebben we een nieuwe regressieanalyse uitgevoerd waarin we 'de ING Bank' en 'de makers van Habbo' als correcte antwoorden voor begrip van de commerciële bron hebben meegenomen. De analyse liet geen significant effect zien voor begrip van de commerciële bron en de effecten van de overige variabelen bleven onveranderd. Dit geeft aan dat zelfs het begrip dat de makers van Habbo betrokken zijn bij het maken van de reclames geen rol speelt in het kritische reclameverwerkingsproces van kinderen.

De bevindingen met betrekking tot reclamewijsheid bevestigen de bestaande inzichten dat conceptuele reclamewijsheid niet automatisch resulteert in het vermogen om kritisch om te gaan met de huidige commerciële mediaomgeving (Livingstone \& Helsper, 2006; Rozendaal et al., 20II). Door de affectieve aard van geïntegreerde reclame in combinatie met de onvolgroeide cognitieve bekwaamheden van kinde- 
ren, is het zeer onwaarschijnlijk dat kinderen hun conceptuele reclamewijsheid aanwenden als afweermechanisme als zij met reclame worden geconfronteerd (zie Buijzen et al., 20I0; Harris, Brownell \& Gargh, 2009; Livingstone \& Helsper, 2006). Onze bevindingen lieten echter zien dat de evaluatieve component van reclamewijsheid wel een rol speelt bij de reclameverwerking van kinderen. Een verklaring hiervoor is dat de evaluatieve component van reclamewijsheid gebaseerd is op andere reclameverwerkingsmechanismen die weinig mentale inspanning of geavanceerde verwerkingsvaardigheden vereisen. Een algemene kritische houding ten opzichte van reclame (bijv. scepticisme en een afkeer van reclame) zorgt automatisch voor een negatief gevoel bij de verwerking van een specifieke reclame, en dat gevoel wordt vervolgens weer overgebracht op de reclame en het geadverteerde merk (MacKenzie \& Lutz, I989; Rozendaal et al., 20II; Zuwerink \& Devine, I996). Ons onderzoek toont aan dat dit effect ook aanwezig is bij reclame in online sociale netwerken.

Tot slot is gebleken dat gevoeligheid voor de mening van peers een sterke voorspeller is voor het verlangen van kinderen naar de geadverteerde merken in online sociale netwerken. Dit betekent dat kinderen die de mening van peers over merken in online sociale netwerken belangrijk vinden, eerder beïnvloed zullen worden door de reclame in de virtuele omgeving. In de onderzochte leeftijdsgroep beginnen kinderen te geloven dat het bezit van bepaalde merken en producten de kwaliteit van hun vriendschap bepaalt. Om die reden is hun bereidheid zich aan te passen aan de peergroep vrij hoog (Banjerjee \& Dittmar, 2008). Onze bevindingen bevestigen dat de peergroep binnen een sociale community een normatieve standaard neerzet met betrekking tot merken die cool en populair zijn, hetgeen de houding ten opzichte van merken en het koopgedrag van de kinderen beïnvloedt (Mangleburg \& Bristol, I998, Mangleburg, Doney \& Bristol, 2004).

\section{Conclusie, beperkingen en implicaties}

Samenvattend heeft onze studie aangetoond dat (I) kinderen een vrij goede kennis hebben van reclame in online sociale netwerken maar er geen kritisch houding tegenover hebben en (2) dat ze beweren niet erg gevoelig te zijn voor de meningen van peers met betrekking tot merken en dat (3) de belangrijkste voorspellers voor het verlangen van kinderen naar merken in online sociale netwerken zijn: een weinig kritische houding en een hoge gevoeligheid voor de meningen van peers met betrekking tot de merken in het spel.

Alvorens de theoretische en praktische implicaties van deze conclusies te bespreken dient eerst een aantal beperkingen te worden toegelicht. Ten eerste was de manier waarop het onderzoek is uitgevoerd niet geheel realistisch, omdat we de kinderen een vooraf gemaakte videocompilatie toonden in plaats van de kinderen zelf in 
Habbo te laten rondlopen. Kinderen zelf laten rondlopen door deze online sociale community zou gevolgen kunnen hebben voor drie factoren: (I) selectieve blootstelling (omdat kinderen normaal gesproken hun eigen route en instellingen bepalen), (2) interactiviteit (omdat zelf het spel spelen actiever is en leidt tot meer betrokkenheid) en (3) het persoonlijk belang (omdat veel sociale media advertenties tonen die zijn aangepast op basis van eerder gedrag van individuen). In toekomstig onderzoek zou onze studie herhaald kunnen worden in een meer natuurlijke omgeving met een specifieke focus op de rol van de drie genoemde factoren. Ten tweede zijn onze bevindingen gebaseerd op correlationele data. Om iets te kunnen zeggen over de causale richting van de gevonden relaties is experimenteel onderzoek nodig. Ten derde kregen de kinderen bij de introductie van het onderzoek te horen dat het over reclame zou gaan. Kinderen zouden daardoor geprimed kunnen zijn om bij het kijken van de videocompilatie op de reclames te letten, wat de bevindingen van het onderzoek beïnvloed kan hebben. In verder onderzoek zou een meer algemene introductie gebruikt kunnen worden om een eventueel priming-effect te voorkomen (bijv. de beleving van Habbo in het algemeen).

Rekening houdend met deze beperkingen, hebben onze bevindingen verschillende belangrijke theoretische en praktische implicaties die bijdragen aan het lopende academische debat over de aard en rol van reclamewijsheid bij kinderen en hun gevoeligheid voor reclame-invloeden. In overeenstemming met andere recente inzichten zagen we dat de conceptuele component van reclamewijsheid (kennis en begrip van reclame) niet gerelateerd is aan het verlangen van kinderen naar het geadverteerde product. Bovendien toonden onze resultaten aan dat de evaluatieve component van reclamewijsheid wel een belangrijke rol speelt bij de gevoeligheid van kinderen voor reclame. Het hebben van een kritische houding ten opzichte van reclame in online sociale netwerken was een van de twee belangrijkste voorspellers voor het verlangen naar geadverteerde merken. Deze bevindingen benadrukken het belang van een focus op de evaluatieve component van reclamewijsheid in verder onderzoek naar geïntegreerde vormen van online reclame. Dit onderzoek zou zich specifiek moeten richten op (I) de aard en de diverse componenten van evaluatieve reclamewijsheid, (2) de ontwikkeling ervan gedurende de kinderjaren en adolescentie en (3) de mediërende en modererende rol in het overtuigingsproces.

Onze bevinding dat gevoeligheid voor de mening van peers de andere grootste voorspeller is bij het verlangen van kinderen naar merken, vraagt ook om verder onderzoek. Alhoewel over het algemeen wordt aangenomen dat peers een cruciale rol spelen in het consumentengedrag van kinderen en hun reacties op reclame, krijgt het onderwerp, juist in deze fase van de sociale ontwikkeling, opmerkelijk weinig aandacht in onderzoeken (John, I999; De Gregorio \& Sung, 2010). Er is een dringende behoefte aan verder onderzoek met een specifieke focus op reclame in sociale media en kinderen die zich in de midden-kindertijd bevinden. Er zou nader onderzocht kunnen worden wat de aard en rol zijn van de verschillende vormen van peerinvloed 
(normatief versus informatief) in de commerciële sociale media. Daarnaast kan toekomstig onderzoek een onderscheid maken tussen invloed van peers en de (al dan niet indirecte) invloed van ouders.

Onze bevindingen tonen ook enkele belangrijke theoretische en praktische gevolgen voor het lopende maatschappelijke en politieke debat over kinderen en reclame. De resultaten van ons onderzoek suggereren dat merkintegratie in online sociale netwerken een mogelijkheid biedt voor adverteerders om kinderen te beïnvloeden. Ons onderzoek laat zien dat vooral kinderen die geen kritische houding hebben ten opzichte van reclame en die heel gevoelig zijn voor de invloed van hun peers makkelijk te beïnvloeden zijn door reclame in online sociale netwerken. Beleidsmakers kunnen deze inzichten gebruiken om een passend reclamebeleid te ontwikkelen. In het huidige reclamebeleid zijn nog geen specifieke regels en richtlijnen opgenomen met betrekking tot reclame in online sociale netwerken voor kinderen. De Dutch Dialogue Marketing Association (DDMA) heeft onlangs wel een voorzet gedaan met de Code Social Media Marketing. In deze code is één specifieke bepaling over kinderen opgenomen, namelijk dat het niet is toegestaan om kinderen jonger dan I2 jaar te stimuleren tot het maken van reclame voor producten of diensten via sociale media. Tot op heden is deze code echter nog niet aangenomen door de Stichting Reclame Code en daarmee ook nog niet in werking getreden.

Naast het beschermen van kinderen tegen reclame door middel van regelgeving, wordt in veel westerse samenlevingen steeds meer aandacht besteed aan methoden om kinderen weerbaarder te maken tegen reclameboodschappen, waaronder educatieve programma's die als doel hebben de reclamewijsheid van kinderen te vergroten. Alhoewel eerdere studies hebben aangetoond dat zulke interventies succesvol kunnen zijn om reclamewijsheid bij kinderen te vergroten (Brucks et al., I988; Donohue, Henke \& Meyer, I983; Feshbach, Feshbach \& Cohen, I982; Hobbs \& Frost, 2003; Roberts et al., I980), hebben verschillende recente studies aangetoond dat reclamewijsheid kinderen niet per definitie in staat stelt zichzelf te weren tegen reclame. Dit onderstreept het belang voor beleidmakers om educatieve interventies te ontwikkelen die gebaseerd zijn op wetenschappelijke kennis over de manier waarop kinderen reclame verwerken, zoals gesteld door Wright et al. (2005), alsmede de noodzaak om de effectiviteit van dergelijke onderwijsprogramma's te onderzoeken.

Ons onderzoek suggereert dat educatieve interventies zich niet alleen zouden moeten richten op de conceptuele component van reclamewijsheid maar ook op de evaluatieve component. Onze resultaten komen overeen met eerder onderzoek waarbij is aangetoond dat het evaluatieve component van reclamewijsheid effectief is bij het beïnvloedingsproces (Buijzen, 2007; Rozendaal et al., 20II). Met andere woorden, in aanvulling op de uitleg van het reclameconcept moeten educatieve interventies zich ook richten op de toepassing van een meer kritische en volwassen houding ten 
opzichte van reclame. Dergelijke interventies zouden een onderscheid moeten maken tussen de verschillende soorten reclame (bijv. overheidscampagnes versus speelgoedreclames) en zich specifiek moeten richten op de niet-traditionele vormen van reclame. Kinderen hebben bij de niet-traditionele vormen van reclame namelijk een minder kritische houding, zoals in deze studie is aangetoond. Kinderen zouden moeten leren dat niet alle persuasieve boodschappen misleidend zijn, maar dat de geloofwaardigheid voor een groot deel afhangt van de bron en het type product waarvoor geadverteerd wordt.

\section{Literatuur}

Auty, S. \& Lewis, C. (2004). Exploring children's choice: The reminder effect of product placement. Psychology \& Marketing, 21 (9), 697-713.

Ali, M., Blades, M., Oates, C. \& Blumberg, F. (2009). Young children's ability to recognize advertisements in web page designs. British Journal of Developmental Psychology, 27, 7I-83.

Banerjee, R. \& Dittmar, H. (2008). Individual differences in children's materialism: The role of peer relations. Personality and Social Psychology Bulletin, 34(I), I7-3I.

Beals, L. \& Bers, M.U. (2009). A developmental lens for designing virtual worlds for children and youth. The International Journal of Learning and Media, 1, 5I-65.

Bearden, W.P., Netemeyer, R.G. \& Teel, J.E. (I989). Measurement of consumer scepticism to interpersonal influence. Journal of Consumer Research, 15, 473-8I.

Beckwith, N.E., Kassarjian, H.H. \& Lehmann, D.R. (1978). Halo effects in marketing research: Review and prognosis. In K. Hunt (ed.), Advances in Consumer Research Volume o5 (pp. 465-467). Association for Consumer Research.

Boush, D.M. (200I). Mediating advertising effects. In J. Bryant \& J.A. Bryant (eds.), Television and the American family, 2nd ed. (pp. 397-412). Mahwah, NJ: Lawrence Erlbaum Associates.

Brucks, M., Armstrong, G.M. \& Goldberg, M.E. (1988). Children's use of cognitive defenses against television advertising: A cognitive response approach. Journal of Consumer Research, I4, 47I-482.

Buijzen, M. (2007). Reducing children's susceptibility to commercials: Mechanisms of factual and evaluative advertising interventions. Media Psychology, 9, 4II-430

Buijzen, M., Van Reijmersdal, E.A. \& Owen, L.H. (20I0). Introducing the PCMC model: An investigative framework for young people's processing of commercial media content. Communication Theory, 20, 427-450.

Butter, E.J., Popovich, P.M., Stackhouse, R.H. \& Garner, R.K. (I98I). Discrimination of television programs and commercials by preschool children. Journal of Advertising Research, 21, 53-56.

Chaiken, S., Liberman, A. \& Eagly, A.H. (I989). Heuristic and systematic information processing within and beyond the persuasion context. In J.S. Uleman \& J.A. Bargh (eds.), Unintended thought (pp. 2I2-252). New York: Guilford Press.

D’Alessio, M., Laghi, F. \& Baiocco. R. (2009). Attitudes toward TV advertising: A measure for children. Journal of Applied Developmental Psychology, 30, 409-4I8.

Davison, W.P. (1983). The third-person effect in communication. Public Opinion Quarterly 47, I-I5.

De Gregorio, F. \& Sung, Y. (20IO). Understanding attitudes toward and behaviors in response to product placement: A consumer socialization framework. Journal of Advertising, 39 (I), 83-96.

Donohue, T.R., Henke, L.L. \& Meyer, T.P. (1983). Learning about television commercials: The impact of instructional units on children's perceptions of motive and intent. Journal of Broadcasting, 27, 25I-26I.

Feshbach, S., Feshbach, N.D. \& Cohen, S.E. (1982). Enhancing children's discrimination in response to television advertising: The effects of psychoeducational training in two elementary school-age groups. Developmental Review, 2, 385-403. 
Fielder, A., Gardner, W., Nairn, A. \& Pitt, J. (2007). Fair game? Assessing commercial activity on children's favourite websites and online environments. National Consumer Council of the United Kingdom. Retrieved November 30 20II from http://www.childnet-int.org/downloads/fair-game-final.pdf.

Friestad, M. \& Wright, P. (I994). The persuasion knowledge model: How people cope with persuasion attempts. Journal of Consumer Research, 21, I-3I.

Gunter, B. \& Furnham, A. (I998). Children as consumers: A psychological analysis of the young people's market. London: Routledge.

Gutnick, A.L., Robb, M., Takeuchi, L. \& Kotler, J. (2010). Always connected: The new digital media habits of young children. New York: The Joan Ganz Cooney Center at Sesame Workshop.

Harris, J.L., Brownell, K.D. \& Bargh, J.A. (2009). The food marketing defense model: Integrating psychological research to protect youth and inform public policy. Social Issues and Policy Review, 3, 2II-27I.

Henriksen, L. \& Flora, J.A. (I999). Third-person perception and children: Perceived impact of pro- and anti-smoking ads. Communication Research, 26(6), 643-665.

Hobbs, R. \& Frost, R. (2003). Measuring the acquisition of media-literacy skills. Reading Research Quarterly, 38, 330-355.

John, D.R. (I999). Consumer socialization of children: A retrospective look at twenty-five years of research. Journal of Consumer Research, 26, I83-213.

Kunkel, D., Wilcox, B.L., Cantor, J., Palmer, E., Linn, S. \& Dowrick, P. (2004). Report of the APA Task Force on advertising and children. Washington, DC: American Psychological Association.

Levin, S.R., Petros, T.V. \& Petrella, F.W. (I982). Preschoolers' awareness of television advertising. Child Development, 53, 933-937.

Livingstone, S. (2009). Debating children's susceptibility to persuasion - where does fairness come in? International Journal of Advertising, 28, I70-174.

Livingstone, S. \& Helsper, E.J. (2006). Does advertising literacy mediate the effects of advertising on children? A critical examination of two linked research literatures in relation to obesity and food choice. Journal of Communication, 56, 560-584.

Lutz, R. J. (I985). Affective and cognitive antecedents of attitude toward the ad: A conceptual framework. In L. Alwitt \& A. Mitchell (eds.), Psychological processes and advertising effects: Theory, research and applications (pp. 45-63). Hillsdale, NJ: Erlbaum.

MacKenzie, S.B. \& Lutz, R.J. (I989). An empirical examination of the structural antecedents of attitude toward the ad in an advertising pretesting context. Journal of Marketing, 53, 48-65.

Mallinckrodt, V. \& Mizerski, D. (2007). The effects of playing an advergame on young children's perceptions, preferences, and requests. Journal of Advertising, 36, 87-100.

Mangleburg, T.F. \& Bristol, T. (I998). Socialization and adolescents' skepticism toward advertising. Journal of Advertising, 27 (3), II-2I.

Mangleburg, T.F., Doney, P.M. \& Bristol, T. (2004). Shopping with friends and teens' susceptibility to peer influence. Journal of Retailing, 80, IOI-II6.

Martin, M.C. (I997). Children's understanding of the intent of advertising: A meta-analysis. Journal of Public Policy Q Marketing, 16, 205-216.

Meyer, D.J.C. \& Anderson, H.C. (2000). Preadolescents and apparel purchasing: Conformity to parents and peers in the consumer socialisation process. Journal of Social Behavior and Personality, 15(2), $243-257$.

Moore, E.S. \& Rideout, V.J. (2007). The online marketing of food to children: Is it just fun and games? Journal of Public Policy Q M Marketing, 26, 202-220.

Moschis, G.P. \& Churchill, Jr., G.A. (I978). Consumer socialization: a theoretical and empirical analysis. Journal of Marketing Research, 15 (4), 599-609.

Nairn, A. \& Fine, C. (2008) Who's messing with my mind? The implications of dual-process models for ethics of advertising to children. International Journal of Advertising, 27, 447-470.

Nelson, M.R. \& McLeod, L.E. (2005). Adolescent brand consciousness and product placements: awareness, liking and perceived effects on self and others. International Journal of Consumer Studies, 29, $515-528$.

Ofcom. (20II). Children and parents: Media use and attitudes report. London, UK. 
Owen, L.H., Lewis, C., Auty, S. \& Buijzen, M., (2009, May). Is children's understanding of nonspot advertising comparable to their understanding of television advertising? Paper presented at the 59th annual meeting of the International Communication Association, Chicago, IL.

Petty, R.E. \& Cacioppo, J.T. (I986). Communication and persuasion: Central and peripheral routes to attitude change. New York: Springer-Verlag.

Roberts, D.F., Christenson, P., Gibson, W.A., Mooser, L. \& Goldberg, M.E. (I980). Developing discriminating consumers. Journal of Communication, 94-105.

Roedder, D.L. (I98I). Age differences in children's responses to television advertising: An informationprocessing approach. Journal of Consumer Research, 8, I44-I53.

Rossiter, J.R. \& Robertson, T.S. (I974). Children's TV commercials: Testing the defenses. Journal of Communication, 24(4), I37-I44.

Rozendaal, E., Buijzen, M. \& Valkenburg, P.M. (2008). Reclamewijsheid in ontwikkeling: Een vergelijking van de cognitieve reclamevaardigheden van kinderen en volwassenen. Tijdschrift voor Communicatiewetenschap, 36, 270-283.

Rozendaal, E., Buijzen, M. \& Valkenburg, P.M. (2009). Do children's cognitive advertising defenses reduce their desire for advertised products? Communications, 34, 287-303.

Rozendaal, E., Buijzen, M. \& Valkenburg, P.M. (20I2). Think-aloud method superior to thought-listing in increasing children's advertising defenses. Human Communication Research, 38, I98-220.

Rozendaal, E, Lapierre, M.A., Van Reijmersdal, E.A. \& Buijzen, M. (20II). Reconsidering advertising literacy as a defense against advertising effects. Media Psychology, 14, 333-54.

Salwen, M.B. \& Dupagne, M. (2003). News of Y2K and experiencing Y2K: Exploring the relationship between the third-person effect and optimistic bias. Media Psychology, 5, 57-82.

Smolders, E. \& Zonjee, S. (2008). Habvertising? Een onderzoek naar de effecten van adverteren en voorlichten in online virtuele wereld Habbo op spelers van Habbo (masterthesis). Opgehaald 3 augustus 20I2 van http://dare.uva.nl/scriptie/28979I.

Stephens, N. \& Stutts, M.A. (I982). Preschoolers' ability to distinguish between television programming and commercials. Journal of Advertising, 11, 16-26.

Sulake (2009). Habbo Hotel offers teenage marketing insight through new conversation measurement tool. Opgehaald 30 november van http://www.sulake.com/press/releases/2009-I2-II-Habble_.html.

Valkenburg, P.M. (2004). Children's responses to the screen: A media psychological approach. Mahwah, NJ: Erlbaum.

Valkenburg, P. M., \& Cantor, J. (200I). The development of a child into a consumer. Journal of Applied Developmental Psychology, 22, 6I-72.

Van Reijmersdal, E.A. (2OII). Mixing advertising and editorial content in radio programmes: Appreciation and recall of brand placements versus commercials. International Journal of Advertising, 30(3), $425-446$.

Van Reijmersdal, E.A., Jansz, J., Peters, O. \& Van Noort, G. (20I0). The effects of interactive brand placements in online games on children's cognitive, affective, and conative brand responses. Computers in Human Behavior, 26, I787-I794.

Van Reijmersdal, E.A., Rozendaal, E. \& Buijzen, M. (20I2). Effects of prominence, involvement, and persuasion knowledge on children's cognitive and affective responses to advergames. Journal of Interactive Marketing, 26, 33-42.

Wright, P., Friestad, M. \& Boush, D.M. (2005). The development of marketplace persuasion knowledge in children, adolescents, and young adults. Journal of Public Policy \& Marketing, 24, 222-233.

Young, B.M. (I990). Television advertising and children. Oxford, UK: Clarendon Press.

Zuwerink, J.R. \& Devine, P.G. (I996). Attitude importance and resistance to persuasion: It's not just the thought that counts. Journal of Personality and Social Psychology, 70, 931-944. 
40 Tijdschrift voor Communicatiewetenschap - 4I [I] 2013

\section{Noten}

I Dit onderzoek is gefinancierd door de Nederlandse Organisatie voor Wetenschappelijk Onderzoek (NWO). De financier heeft geen rol gehad in het onderzoek of het artikel. 